\title{
Unexplained Increase in Serum Corticosteroid-Binding Globulin Levels in a Patient with Chronic Thyroiditis, Pituitary Adenoma and Empty Sella
}

\author{
Katsuyoshi TOJO, Yuji OHNO*, Masahiro KAWAMURA*, and Osamu SAKAI \\ Second Department of Internal Medicine and * First Department of Pharmacology, \\ The Jikei University School of Medicine, Tokyo 105, Japan
}

\begin{abstract}
Unexplained high serum corticosteroid-binding globulin (CBG) concentrations (mean \pm SD, $74.1 \pm 12.1 \mu \mathrm{g} / \mathrm{d} l$; normal women, $32.5 \pm 5.6 \mu \mathrm{g} / \mathrm{d} l$ ) were found in an unmarried woman who was not pregnant or taking exogenous estrogens. She was also found to suffer from subclinical chronic thyroiditis, pituitary adenoma and empty sella. The increased serum CBG concentrations in this patient were not due to any of the factors known to increase CBG. Consistently high basal serum GH levels and unusual GH responses to GH-releasing factor (GRF) and L -dopa were also noted.
\end{abstract}

Key words: Hypercortisolemia, Corticosteroid-binding globulin, Pituitary adenoma, Chronic thyroiditis, Abnormal GH secretion

(Endocrine Journal 43: 665-670, 1996)

CORTICOSTEROID-binding globulin (CBG) is a plasma $\alpha 1$-glycoprotein of hepatic origin with a molecular weight of approximately 52000 . CBG is the major transport protein for glucocorticoids in the blood. Under normal physiological conditions, more than $90 \%$ of circulating cortisol is bound to CBG in humans [1]. This CBG-bound cortisol is considered to be biologically inactive, whereas the unbound cortisol constitutes the active form of cortisol. The active fraction of plasma cortisol will thus depend on the concentration of CBG. The serum CBG concentrations vary little diurnally and are similar in men and women [2]. It is generally agreed that there is little or no variation in serum CBG concentrations during the menstrual cycle [3, $4]$.

Abnormally low serum CBG levels are found in

Received: March 28, 1996

Accepted: July 1, 1996

Correspondence to: Dr. Katsuyoshi TOJO, Second Department of Internal Medicine, The Jikei University School of Medicine, 3-25-8 Nishi-shinbashi, Minato-ku, Tokyo 105, Japan a variety of diseases [2], and hereditary CBG deficiency has also been described [5-7]. Elevated serum CBG concentrations, on the other hand, are usually caused by estrogen therapy or pregnancy. In addition, increased serum CBG levels have been noted in $25-30 \%$ of patients with acute lymphocytic and myelocytic leukemia [8] and $80 \%$ of chronic active hepatitis [9]. In contrast, there is considerably less evidence for high serum CBG levels of unknown origin $[10,11]$. The following case report details a woman with increased serum CBG levels but without the other estrogen-associated changes in blood proteins. Furthermore, chronic thyroiditis, pituitary adenoma with empty sella and consistently high basal serum GH levels with paradoxical $\mathrm{GH}$ responses to $\mathrm{GH}$-releasing factor (GRF) and L-dopa were also noted in this patient.

\section{Case Report}

A 41-year-old unmarried woman was referred to the endocrine clinic for exploration of the pituitary-adrenal axis after she was found to have a 
high morning serum cortisol concentration $(27 \mu \mathrm{g} /$ $\mathrm{d} l$; normal, $4.0-18.3 \mu \mathrm{g} / \mathrm{d} l$ ). Over the previous 6 months she had been aware of alopecia and consulted a dermatologist. She has no particular medical history. She was not taking any medication, had regular menstrual cycles, and was not pregnant. There was no history of diabetes mellitus or hypertension in her family and no other evidence of endocrine abnormalities. Her height was $160 \mathrm{~cm}$ and she weighed $54 \mathrm{~kg}$. Her blood pressure was $134 / 86 \mathrm{mmHg}$. On physical examinations, she was apparently in good health. The thyroid gland was not palpable. Central obesity, moon face, buffalo hump and cutaneous striae were not observed. Visual acuity was normal. Neurological examination was negative.

Routine laboratory examinations showed a red blood cell count of $4.21 \times 10^{6} / \mu l$, and a hemoglobin count of $13.7 \mathrm{~g} / \mathrm{dl}$. The eosinophil count was $0.22 \times 10^{3} / \mu l$. The white blood cell count was $4.2 \times$ $10^{3} / \mu \mathrm{l}$. Fasting blood glucose was $105 \mathrm{mg} / \mathrm{dl}$, and $\mathrm{HbA} 1 \mathrm{C}$ was $4.7 \%$. An oral glucose tolerance test showed a pattern of impaired glucose tolerance. Urea nitrogen, creatinine and liver function tests were normal. Serum $\mathrm{Na}$ was $142 \mathrm{mmol} / l$, serum $\mathrm{K}, 4.5 \mathrm{mmol} / \mathrm{l}$ and serum $\mathrm{Cl}, 106 \mathrm{mmol} / l$. Serum $\mathrm{Ca}$ was $9.6 \mathrm{mg} / \mathrm{d} l$. Urinary sugar and protein were negative. Baseline endocrine results are as follows. Serum cortisol ( $\gamma$-coat cortisol kit, Baxter Travenol Co., Tokyo) was consistently high $(29.0 \pm 3.9 \mu \mathrm{g} /$ $\mathrm{d} l$; normal range, 4.0-18.3 $\mu \mathrm{g} / \mathrm{d} l$ ), while serum ACTH (Allegro ACTH kit, Nihon Medi-Physics, Takarazuka) remained high normal $(41 \pm 11.8 \mathrm{pg} /$ $\mathrm{ml}$; normal range, $9-52 \mathrm{pg} / \mathrm{ml}$ ). Urinary free cortisol was $64.6 \pm 9.2 \mu \mathrm{g} /$ day (normal range, $30-100$ $\mu \mathrm{g} /$ day), urinary 17-hydroxycorticosteroid (17OHCS) was $8.4 \mathrm{mg} /$ day (normal range, $2.2-7.3 \mathrm{mg} /$ day), urinary 17-ketosteroid was $6.5 \mathrm{mg} /$ day (normal range, 2.4-11.0 mg/day). Serum GH (GH kit, Daiichi Radioisotope Lab) was also consistently high $(21.2 \pm 7.6 \mathrm{ng} / \mathrm{ml}$; normal range, $0.66-3.68$ $\mathrm{ng} / \mathrm{ml}$ ), whereas serum somatomedin C (SmC) (Somatomedin C.II Chiba Coaning kit, Chiba.Coaning Diagnostic Co., Tokyo) was within normal limits (140 $\mathrm{ng} / \mathrm{ml}$; normal range, 79-383 ng/ml). Urinary $\mathrm{GH}$ excretion was very high $(41.4 \mathrm{pg} / \mathrm{mg}-\mathrm{Cr}$; normal range, $6.2 \pm 3.3 \mathrm{pg} / \mathrm{mg}-\mathrm{Cr}$ ). Serum TSH (TSH RIABEAD II kit, Dinabott, Tokyo), free triiodothyronine (T3) (Amerlex-M FT3, Amersham International, Tokyo) and free thyroxine (T4)
Table 1. Dynamic assessments for pituitary-adrenal axis

\begin{tabular}{|c|c|c|}
\hline $\begin{array}{l}\text { 1. Diurnal variation } \\
\text { ACTH }(\mathrm{pg} / \mathrm{m} l) \\
\text { Cortisol }(\mu \mathrm{g} / \mathrm{d} l)\end{array}$ & $\begin{array}{c}0800 \mathrm{~h} \\
86 \\
27.0\end{array}$ & $\begin{array}{c}1600 \mathrm{~h} \\
67 \\
19.9\end{array}$ \\
\hline \multicolumn{3}{|c|}{ 2. Rapid ACTH test $\left({ }^{1-25} \mathrm{ACTH} 0.25 \mathrm{mg}\right.$ i.v. $)$} \\
\hline Cortisol $(\mu \mathrm{g} / \mathrm{d} l)$ & $\begin{array}{c}30 \\
31.8\end{array}$ & $\begin{array}{l}60(\min ) \\
40.6\end{array}$ \\
\hline $\begin{array}{l}\text { 3. Dexamethasone suppression t } \\
\text { (1) Dexamethasone } 0.5 \mathrm{mg} \text { p.o. } \\
\text { ACTH }(\mathrm{pg} / \mathrm{ml}) \\
\text { Cortisol }(\mu \mathrm{g} / \mathrm{d} l)\end{array}$ & $\begin{array}{c}\text { Pre } \\
42 \\
25.6\end{array}$ & $\begin{array}{c}\text { Post } \\
14 \\
4.1\end{array}$ \\
\hline $\begin{array}{l}\text { (2) Dexamethasone } 1.0 \mathrm{mg} \text { p.o. } \\
\text { ACTH }(\mathrm{pg} / \mathrm{m} l) \\
\text { Cortisol }(\mu \mathrm{g} / \mathrm{d} l)\end{array}$ & $\begin{array}{c}\text { Pre } \\
45 \\
28.7\end{array}$ & $\begin{array}{l}\text { Post } \\
\leqq 5 \\
2.6\end{array}$ \\
\hline
\end{tabular}

(Amerlex-M FT4) were within normal limits (3.0 $\mu \mathrm{U} / \mathrm{ml}$; normal range, $0.34-3.5 \mu \mathrm{U} / \mathrm{ml}, 2.7 \mathrm{pg} / \mathrm{ml}$; normal range, $2.47-4.34 \mathrm{pg} / \mathrm{ml}$, and $1.03 \mathrm{ng} / \mathrm{dl}$; normal range, $0.97-1.79 \mathrm{ng} / \mathrm{d} l$, respectively). Serum thyroxine-binding globulin (TBG) (RIAgnost TBG kit, Hoechst Japan, Tokyo) was $22 \mu \mathrm{g} / \mathrm{ml}$ (normal range, 14-28 $\mu \mathrm{g} / \mathrm{ml}$ ). TSH-binding inhibitory immunoglobulins (TBII) (TRAb kit, Baxter Travenol Co., Tokyo) was negative (7.4\%; normal range, $<15 \%$ ). TgAb (TgAb Cosmic kit, Cosmic Co., Tokyo) and TPOAb (TPOAb Cosmic kit, Cosmic Co., Tokyo) were positive $(1.9 \mathrm{U} / \mathrm{ml}$; normal range, $\leqq$ $0.3 \mathrm{U} / \mathrm{ml}$ and $56.0 \mathrm{U} / \mathrm{ml}$; normal range, $\leqq 0.3 \mathrm{U} /$ $\mathrm{ml}$, respectively), suggesting that she suffered from chronic thyroiditis. Dynamic assessments for the pituitary-adrenal axis are shown in Table 1. The diurnal rhythm of serum ACTH and cortisol appeared normal $(86 \mathrm{pg} / \mathrm{ml}$ and $27.0 \mu \mathrm{g} / \mathrm{d} l$ at 0800 $\mathrm{h}, 67 \mathrm{pg} / \mathrm{ml}$ and $19.9 \mu \mathrm{g} / \mathrm{d} l$ at $1600 \mathrm{~h}$, respectively). Serum cortisol showed normal responses to ${ }^{1-25}$ ACTH (0.25 mg i.v.). Serum ACTH and cortisol showed normal suppression after administration of 0.5 and $1 \mathrm{mg}$ dexamethasone at $2300 \mathrm{~h}$ the day before. Pituitary function was tested with TRH (500 $\mu$ g i.v.), LH-RH (100 $\mu$ g i.v.), corticotropin-releasing factor (CRF; $100 \mu \mathrm{g}$ i.v.), GH-releasing factor (GRF; $100 \mu$ i.v.), $75 \mathrm{~g}$ glucose and L-dopa (500 mg p.o.), and the results are shown in Table 2. The high GH and normal SmC levels in conjunction with paradoxical responses of GH to GRF and L-dopa are isolated since thyroid and adrenal functions were normal, as were basal and stimulated gonadotropin and PRL lev- 
Table 2. Provocation tests for pituitary hormone secretion

\begin{tabular}{|c|c|c|c|c|c|c|}
\hline & 0 & 15 & 30 & 60 & 90 & 120 (min) \\
\hline \multicolumn{7}{|c|}{ 1. CRH·GRF·TRH·LHRH test (CRH $100 \mu \mathrm{g}$, GRF $100 \mu \mathrm{g}$, TRH $500 \mu \mathrm{g}, \mathrm{LH}-\mathrm{RH} 100 \mu \mathrm{g})$} \\
\hline $\mathrm{ACTH}(\mathrm{pg} / \mathrm{ml})$ & 71 & 150 & 140 & 78 & 45 & 26 \\
\hline Cortisol $(\mu \mathrm{g} / \mathrm{d} l)$ & 25.0 & 27.7 & 29.4 & 29.9 & 21.8 & 17.8 \\
\hline \multicolumn{7}{|l|}{$\mathrm{GH}(\mathrm{ng} / \mathrm{ml})$} \\
\hline 1st time & 21 & - & 18 & 7.4 & 3.7 & 2.3 \\
\hline 2nd time & 33.7 & 27.3 & 21 & 8.65 & 3.48 & 1.42 \\
\hline $\mathrm{TSH}(\mu \mathrm{U} / \mathrm{m} l)$ & 2.9 & - & 34 & 21 & 11 & 7.2 \\
\hline PRL (ng/ml) & 17 & - & 75 & 32 & 16 & 11 \\
\hline $\mathrm{LH}(\mathrm{mIU} / \mathrm{ml})$ & 3.5 & - & 24 & 19 & 15 & 15 \\
\hline $\mathrm{FSH}(\mathrm{mIU} / \mathrm{m} l)$ & 2.9 & - & 7.0 & 7.9 & 8.1 & 7.8 \\
\hline \multicolumn{7}{|l|}{ 2. $75 \mathrm{~g}$ OGTT } \\
\hline Plasma glucose $(\mathrm{mg} / \mathrm{d} l)$ & 95 & - & 246 & 221 & 200 & 165 \\
\hline IRI $(\mu \mathrm{U} / \mathrm{m} l)$ & 3.3 & - & 58 & 40 & 47 & 30 \\
\hline $\mathrm{GH}(\mathrm{ng} / \mathrm{m} l)$ & 14 & - & 2.66 & 0.84 & 0.44 & 2.79 \\
\hline \multicolumn{7}{|c|}{ 3. L-dopa test (L-dopa $500 \mathrm{mg}$ p.o.) } \\
\hline $\mathrm{GH}(\mathrm{ng} / \mathrm{m} l)$ & 23.9 & - & 11.6 & 6.41 & 1.49 & 0.51 \\
\hline \multicolumn{7}{|c|}{ 4. Vehicle control (Saline $20 \mathrm{ml}$ ) } \\
\hline $\mathrm{GH}(\mathrm{ng} / \mathrm{ml})$ & 11.7 & 16.4 & 9.0 & 3.2 & 5.5 & 2.7 \\
\hline
\end{tabular}

Table 3. Serum CBG, total cortisol and unbound cortisol levels

\begin{tabular}{lccccc}
\hline & No & $\begin{array}{c}\mathrm{CBG} \\
(\mu \mathrm{g} / \mathrm{d} l)\end{array}$ & $\begin{array}{c}\text { Total cortisol } \\
(\mu \mathrm{g} / \mathrm{d} l)\end{array}$ & $\begin{array}{c}\text { Unbound cortisol } \\
(\mathrm{ng} / \mathrm{m} l)\end{array}$ & $\begin{array}{c}\text { Unbound cortisol } \\
(\% \text { of total cortisol) }\end{array}$ \\
\hline Normal [12] & 31 & $33.2 \pm 5.1$ & $11.1 \pm 4.9$ & $8.8 \pm 5.3$ & $7.9 \pm 3.5$ \\
Men [12] & 16 & $33.8 \pm 4.6$ & $13.2 \pm 5.2$ & $10.7 \pm 6.0$ & $7.7 \pm 1.9$ \\
Women [12] & 15 & $32.5 \pm 5.6$ & $9.0 \pm 3.7$ & $5.6 \pm 3.4$ & $8.1 \pm 4.7$ \\
Present case & & $74.1 \pm 12.1$ & $29.0 \pm 3.9$ & $7.36 \pm 0.4$ & $2.69 \pm 0.39$ \\
\hline
\end{tabular}

Table 4. Serum concentration of the estrogen-responsive proteins

\begin{tabular}{lcc}
\hline & Present case & Normal range \\
\hline Albumin $(\mathrm{g} / \mathrm{d} l)$ & 4.5 & $3.5-5.2$ \\
TBG $(\mu \mathrm{g} / \mathrm{d} l)$ & 22 & $14-28$ \\
Ceruloplasmin $(\mathrm{mg} / \mathrm{d} l)$ & 32.6 & $20-60$ \\
Haptoglobin $(\mathrm{mg} / \mathrm{d} l)$ & 156 & $160-300$ \\
\hline
\end{tabular}

els. Pituitary magnetic resonance imaging (MRI) showed pituitary microadenoma and empty sella; herniation of suprasellar cistern into anterior sella turcia, whereas abdominal computed tomography (CT) revealed a normal adrenal gland. Because of the marked discrepancy between serum cortisol and urinary free cortisol levels, serum CBG con- centrations were measured by radio-immunoassay (CBG-RIA kit, Medgnix Co., Belgium). Her serum CBG concentration, when first measured, was 94.7 $\mu \mathrm{g} / \mathrm{ml}$ (normal women, $32.5 \pm 5.6 \mu \mathrm{g} / \mathrm{ml}$ ). Thereafter, her CBG concentration has remained consistently high $(74.1 \pm 12.1 \mu \mathrm{g} / \mathrm{ml})$ independent of the menstrual cycle, and serum bioactive unbound cortisol levels in the present patient were within normal limits $(7.36 \pm 0.4 \mathrm{ng} / \mathrm{ml}$; normal women, $5.6 \pm 3.4 \mathrm{ng} / \mathrm{ml}$ ) (Table 3). Serum sex hormone-binding globulin (SHBG), also measured by RIA (Delfia SHBG kit, Wallac Oy, Turku, Finland), was normal ( $69 \mathrm{nmol} / l$; normal women, 65 $\pm 39 \mathrm{nmol} / l$ ). In addition, serum concentrations of other estrogen-responsive proteins such as TBG, ceruloplasmin, haptoglobin and albumin were normal (Table 4). 


\section{Discussion}

The increased serum CBG concentration in the present patient was not due to any of the factors known to increase CBG, such as pregnancy or estrogen administration. The concentration of each of the estrogen-responsive proteins including TBG, ceruloplasmin, haptoglobin and albumin, was within the normal range, supporting the negative history of estrogen medication, and the endogenous serum estradiol concentration was normal. She was apparently in good health. She did not suffer from diabetes mellitus or tuberculosis, which have been associated with slightly increased serum CBG concentrations [13, 14]. There was no evidence of lymphoproliferative disease or chronic active hepatitis, other causes that have been reported in association with increased serum CBG $[8,9]$. Finally, repeated measurements ruled out mere coincidence. It would be reasonable to ascribe the increase in serum CBG in the present patient to heredity, analogous to the well known inheritance of high serum TBG [15] and low serum CBG concentrations $[5,6]$, although the serum CBG concentrations of other family members have not yet been measured. In fact, a similar observation was reported previously [10]. Since no obvious inherited trait could be detected in any family, the inheritance of increased serum CBG levels cannot yet be established definitely, although there is good evidence for the inheritance of low and high CBG levels in animals [16]. So far, the molecular basis of high serum CBG levels of unknown origin has not yet been elucidated. Several possible mechanisms may be considered. The pathogenesis of hemophilia B, one form of the inherited, X-linked, bleeding disorders, has recently been attributed to the mutations at -20 and -26 in the clotting factor IX promoter, leading to impaired transcription by disrupting the binding site for the liver-enriched transcription factor LF-A1/HNF4 [17]. Similarly, it may also be possible to suggest that enhanced promoter activity causes exaggerated transcription, leading to high serum CBG levels. Most recently, Mori et al. [18] demonstrated that gene amplification of TBG is the cause of inherited TBG excess in two Japanese families by evaluating the gene dosage of TBG relative to those of $\beta$-globin and Duchenne muscular dystrophy by coamplification of these target genes by using polymerase chain reaction and subsequent quantification by HPLC. The same mechanism should be also considered in case of inherited CBG excess. Further studies are necessary to determine the yet unknown causes of high CBG levels. Whether an incidentally discovered pituitary microadenoma is functioning or not remains inconclusive at present. Careful followup study is necessary.

The cause of an abnormal GH secretory pattern remains unknown. Basal serum GH levels repeatedly measured were consistently high, while serum SmC levels were within normal limits. Furthermore, a decrease in serum GH in response to GRF and L-dopa administration was observed. The discrepancy between serum GH levels and SmC levels is usually observed in patients with chronic renal failure, chronic liver disease such as chronic hepatitis and cirrhosis of the liver, and a hyponutritional state, all of which are unlikely in the present patient. Exaggerated urinary GH excretion with normal renal function also reflects overproduction of GH. In addition, normal suppression of serum $\mathrm{GH}$ levels by glucose tolerance test excludes the possibility of acromegaly. One possible reason for unexplained high GH levels may be a kind of emotionally stressful situation caused by suffering from alopecia. GH is responsive to a variety of stressful stimuli [19]. Increases in GH occur during surgery, cardiac catheterization, electroshock therapy, gastroscopy, physical exercise, and stimuli of a more purely psychological nature [20]. But, even in such cases, the GH response to GRF and L-dopa may have only a blunted pattern. Furthermore, $\mathrm{GH}$ is secreted episodically, and the rate of change in blood levels is rapid. The episodic nature of $\mathrm{GH}$ secretion complicates interpretation of the response of the hormone to various stimuli. To elucidate a possible involvement of episodic and pulsatile manner of $\mathrm{GH}$ secretion during provocation tests, saline solution was injected as a vehicle control and serum GH levels were measured for up to $2 \mathrm{~h}$. As shown in Table 3, serum GH levels fell spontaneously from $11.7 \mathrm{ng} / \mathrm{ml}$ to $2.7 \mathrm{ng} / \mathrm{ml}$, suggesting that the episodic and pulsatile GH secretion may be, at least in part, involved in abnormal GH responses to provocation tests. Finally, the possibility that biologically inactive $\mathrm{GH}$ is secreted into the general circulation should also be considered. The pathophysiological role of emp- 
ty sella noted in this patient seems unlikely. It is now generally accepted that the finding of an empty or partially empty sella on routine MRI of the brain is of no clinical significance [21]. Dynamic endocrine tests on hypothalamic pituitary function in patients with a primary empty sella syndrome revealed that only 16 of 52 patients had endocrine problems [22]. Among them, hyperprolactinemia was found in 17 patients and panhypopituitarism in 3 patients, and both of these conditions were not noted in the present patient. Further studies are necessary to clarify the mechanism of abnormal GH secretion.

In conclusion, we reported a patient presenting with high serum CBG levels without evidence of excessive endogenous estrogen secretion, exogenous estrogen administration or any other cause. Careful follow-up study will give new insight into the reason for such unexplained high serum CBG concentrations.

\section{References}

1. Siiteri PK, Murai JT, Hammond GL, Nisker JA, Raymoure WJ, Kuhn RW (1982) The Serum transport of steroid hormones. Recent Prog Horm Res 38: 457-510.

2. Coolens JL, Van Baelen H, Heyns W (1987) Clinical use of unbound plasma cortisol as calculated from total cortisol and corticosteroid-binding globulin. J Steroid Biochem 26: 197-202.

3. Hammond G, Lahteenmaki PL, Lahteenmaki P, Luukkainen T (1982) Distribution and percentages of non-contraeptive steroids in human serum. J Steroid Biochem 17: 375-380.

4. Moore D, Kawagoe S, Davajan V, Mishell D, Nakamura R (1978) An in vivo system in man for quantitation of estrogenicity. I. Physiologic changes in binding capacity of serum corticosteroid-binding globulin. Am J Obstet Gynecol 130: 475-481.

5. De Moor P, Hendrickx A, Steeno O (1965) Idiopathic lowering of the cortisol binding capacity of human plasma transcortin. Ann Endocrinol (Paris) 26: 488-493.

6. Lohrenz FN, Seal US, Doe RP (1967) Adrenal function and serum protein concentrations in a kindred with decreased corticosteroid binding globulin (CBG) concentration. J Clin Endocrinol Metab 27: 966972.

7. Roiman A, Bruchis S, Bauman B, Kaufman H, Laron Z (1984) Total deficiency of corticosteroid-binding globulin. Clin Endocrinol (Oxf) 21: 541-548.

8. De Moor P, Louwagie A, Van Baelen H, Van De Putte I (1980) Unexplained high transcortin levels in patients with various hematological disorders and in their relatives: A connection between these high transcortin levels and HLA antigen B12. J Clin Endocrinol Metab 50: 421-426.

9. Orbach O, Schussle A (1989) Increased serum cortisol binding in chronic active hepatitis. Am J Med 86: $39-44$.

10. Lohrenz F, Doe RP, Seal US (1968) Idiopathic or genetic elevation of corticosteroid-binding globu- lin? J Clin Endocrinol Metab 28: 1073-1075.

11. Coolens JL, Heyns W (1989) Marked elevation and cyclic variation of corticosteroid-binding globulin: An inherited abnormalities. J Clin Endocrinol Metab 68: 492-494.

12. Demura R, Terasaki K, Jibiki K, Odagiri E, Demura H, Suda T, Shizume K (1987) A case of Cushing's syndrome associated with CBG deficiency. J Tokyo Women's Med Coll 57: 377-384.

13. De Moor P, Heyns W (1967) Cortisol binding capacity of plasma transcortin in diabetic subjects. $J$ Clin Endocrinol Metab 27: 706-708.

14. De Moor P, Demedts M, Faict D, Gyselen A (1984) Transient high transcortin levels in patients with sputum positive pulmonary tuberculosis. Acta Clin Belg 39: 358-362.

15. Shane S, Seal U, Jones J (1971) X-chromosome linked inheritance of elevated thyroxine-binding globulin in association with goiter. J Clin Endocrinol Metab 32: 587-594.

16. Faict D, De Moor P, Bouillon R (1986) Transcrotin and vitamin D-binding protein levels in mouse serum. J Endocrinol 109: 141-147.

17. Crossley M, Ludwig M, Stowell KM, Vos PD, Olek K, Brownleet GG (1992) Recovery from hemophilia B Leyden: An androgen-responsive element in the factor IX promoter. Science 257: 377-379.

18. Mori $Y$, Miura $Y$, Takeuchi H, Igarashi $Y$, Sugiura J, Saito H, Oiso $Y$ (1995) Gene amplification as a cause of inherited thyroxine-binding globulin excess in two Japanese families. J Clin Endocrinol Metab 80: 3758-3762.

19. Brown GM, Seggie JA, Chambers JW, Ettigi PG (1978) Psychoendocrinology and growth hormone: A review. Psychoneuroendocrinology 3: 131-153.

20. Schalch DS (1967) The influence of physical stress and exercise on growth hormone and insulin secretion in man. J Lab Clin Med 69: 256-269.

21. Hardjasudarma M, White KE, Nandy I, Burns PL (1994) Sellar emptiness on routine magnetic reso- 
nance imaging. South Med J 87: 340-343.

22. Buchfelder M, Brockmeier S, Pichl J, Schrell U, Fahlbusch R (1989) Results of dynamic endocrine testing of hypothalamic pituitary function in patients with a primary "Empty" sella syndrome. Horm Metab Res 21: 573-576. 